\title{
Jurist-Diction
}

Volume 3 No. 6, November 2020

\section{Penyelesaian Sengketa Pajak Daerah Atas Bea Perolehan Hak Atas Tanah dan Bangunan di Kabupaten Sidoarjo}

\author{
Dhimas Adhi M \\ mahardika.dhimas@gmail.com \\ Universitas Airlangga
}

How to cite:

Dhimas Adhi M, 'Penyelesaian

Sengketa Pajak Daerah Atas

Bea Perolehan Hak Atas Tanah

dan Bangunan di Kabupaten

Sidoarjo' (2020) Vol. 3 No. 6

Jurist-Diction.

Histori artikel:

Submit 1 September 2020;

Diterima 22 September 2020;

Diterbitkan 1 November 2020.

DOI:

10.20473/jd.v3i6.22960

\begin{abstract}
Abstrak
Artikel ini berjudul "Kepastian Hukum Dalam Penyelesaian Sengketa Pajak Daerah Atas BPHTB" yang dalam penulisannya menggunakan metode Penelitian doktrinal dengan pendekatan perundang-undangan dan pendekatan konseptual. Bea Perolehan Hak Atas Tanah dan Bangunan merupakan salah satu penyumbang terbesar dalam Pendapatan Asli Daerah. Bea Perolehan Hak Atas Tanah dan Bangunan ini diatur dalam Undang-Undang Nomor 28 tahun 2009 tentang Pajak Daerah dan Retribusi Daerah jo Peraturan Daerah Nomor 5 tahun 2010 tentang Bea Perolehan Hak Atas Tanah dan Bangunan. Dalam Pelaksanaan penentuan penetapan besaran BPHTB tersebut terdapat permasalahan yang timbul dikarenakan sesuai perundang-undangan adalah transaksi namun oleh petugas pemungutan BPHTB ditentukan mengunakan harga pasar, zonasi atau lainnya sesuai dengan subyektifitas petugas pemungut, sehingga memunculkan ketidakpastian hukum. Permasalahan tersebut dapat diselesaikan dengan cara negosiasi antara wajib pajak dengan petugas pajak, Khususnya di daerah Sidoarjo belum pernah terjadi permasalahan BPHTB tersebut menjadi sengketa di pengadilan pajak karena seluruh permasalahan tersebut dapat diselesaikan pada saat adanya pemeriksaan pajak.

Kata Kunci: Pajak Daerah; Sengketa Pajak; Negosiasi.
\end{abstract}

\section{Pendahuluan}

Dalam pembangunan nasional membutuhkan dana yang tidak sedikit dimana dana ini didapatkan dari pajak yang dibayar oleh masyarakat kepada negara. Pajak merupakan pungutan wajib yang dibayar rakyat untuk negara dan akan digunakan untuk kepentingan pemerintah dan masyarakat umum. Pajak menjadi salah satu faktor penting untuk kehidupan bernegara,khususnya dalam hal pembangunan karena pajak merupakan salah satu pendapatan utama negara. Untuk mendukung pembangunan nasional dimana kebutuhan dana itu tidak sedikit dan dana itu didapatkan antara lain dari sektor pajak. Mengenai pemungutan pajak itu sendiri diatur di dalam Pasal 23A Undang-Undang Dasar Negara Republik Indonesia 1945 
dan perubahannya yang berbunyi pajak dan pungutan lain yang bersifat memaksa untuk keperluan negara diatur di dalam undang-undang sehingga mengenai pemungutan pajak ini bersifat memaksa dikarenakan memuat sanksi hukum berupa sanksi administrasi maupun sanksi pidana.

Pemungutan pajak ini sudah diatur didalam undang-undang yang berlaku namun tetap saja terdapat permasalahan yang timbul dikarenakan adanya suatu ketidakpuasan dari para wajib pajak terhadap penetapan besarnya pajak yang ditetapkam oleh petugas pajak yang dapat menyebabkan timbulnya sengketa pajak . Pengertian dari sengketa pajak adalah Sengketa yang timbul dalam bidang perpajakan antara wajib pajak atau penanggung pajak dengan pejabat yang berwenang sebagai akibat dikeluarkannya keputusan yang dapat diajukan banding atau gugatan melalui pengadilan pajak berdasarkan peraturan perundang-undangan perpajakan, termasuk gugatan atas pelaksanaan penagihan berdasarkan Undang undang Penagihan Pajak dengan Surat Paksa. 3 faktor utama yang menyebabkan hal ini dapat terjadi. Pertama perbedaan penafsiran atas ketentuan mengenai jumlah pajak yang disetor ke Negara hal ini dapat terjadi karena misalnya saja mengenai pajak restauran dimana wajib pajak harus melakukan pembayaran pajak ini berdasarkan prinsip selfassesmentyang mewajibkan wajib pajak untuk menghitung, memperhitungkan, membayar sendiri dan melaporkan pajak yang mana petugas pajak juga memiliki penghitungannya sendiri namun sesuai dengan aturannya hal inilah yang biasanya menyebabkan perbedaan jumlah pajak yang disetor. Kedua, terbatasnya kemampuan tenaga pajak, dan ketiga menyebabkan kurangnya koordinasi dalam pelaksanaan pemungutan pajak antara wajib pajak dan tenaga pajak hal dapat terjadi jika kurangnya adanya pemberian informasi-informasi dapat juga karena kurangnya pemahaman dari para wajib pajak itu sendiri. Dari penjelasan diatas maka dapat beberapa permasalahan yang dapat ditemui dalam pemungutan pajak BPHTB ini yang antara lain :

1. Permasalahan pemungutan pajak Bea Perolehan Hak Atas Tanah dan Bangunan di daerah Sidoarjo;

2. Penyelesaian sengketa Pajak Bea Perolehan Hak atas Tanah dan Bangunan di Pemerintah Kabupaten Sidoarjo. 


\section{Tipe Penelitian}

Tipe penelitian yang dipakai adalah penelitian hukum normatif yaitu teknik atau prosedur dengan telaah yang berpedoman pada beberapa asas hukum. Kaidahkaidah hukum, maupun prinsip-prinsip hukum yang berkaitan dengan substansi peraturan perundang-undangan yang bersifat umum dan khusus, sehingga dapat menjawab atas isu hukum yang ada. ${ }^{1}$

\section{Pemungutan Bea Perolehan Hak Atas Tanah dan Bangunan}

Filosofi utama yang melandasi pajak ialah peran serta masyarakat dalam pembangunan dan meningkatkan kesejahteraan serta kemakmuran rakyat melalui peningkatan penerimaan Negara dengan cara pengenaan pajak. Namun demikian timbul sebuah pertanyaan mengapa BPHTB dinamai Bea, bukan Pajak, Tidak banyak yang tahu mengapa BPHTB dinamai dengan bea dan bukan pajak. ${ }^{2}$ Ternyata ada beberapa ciri khusus yang membuatnya dinamai bea, antara lain:

- Ciri pertama, saat pembayaran pajak terjadi lebih dahulu daripada saat terutang. Contohnya, pembeli tanah bersertifikat sudah diharuskan membayar BPHTB sebelum terjadi transaksi (sebelum akta dibuat dan ditandatangani). Hal ini terjadi juga dalam Bea Meterai. Siapapun pihak yang membeli meterai tempel berarti ia sudah membayar Bea Meterai, walaupun belum terjadi saat terutang pajak.

- Ciri kedua adalah frekuensi pembayaran bea terutang dapat dilakukan secara insidentil ataupun berkali-kali dan tidak terikat dengan waktu. Misalnya membeli (membayar) meterai tempel dapat dilakukan kapan saja, demikian pula membayar BPHTB terutang. Hal ini tentunya berbeda dengan pajak, yang harus dibayar sesuai dengan waktu yang sudah ditentukan.

Bea Perolehan Hak atas Tanah dan atau Bangunan dikenakan terhadap orang atau badan yang memperoleh hak atas tanah dan atau bangunan. Perolehan

\footnotetext{
1 Peter Mahmud Marzuki, Penelitian hukum edisi revisi (Kencana Pramedia Grup 2015). [60].

2 Najah Aqila Yunisha Kiai Demak dan Linda Lambey, 'Evaluasi Pemungutan Bea Perolehan Hak Atas Tanah dan Bangunan (BPHTB) di Dinas Pendapatan Pengelolaan Keuangan dan Aset Daerah (DPPKAD) Kota Gorontalo'(2016) 4 Jurnal Emba.[3].
} 
atas suatu hak atas tanah dan atau bangunan ini bisa diartikan bahwa orang atau badan tersebut mempunya nilai lebih atas tambahan atau perolehan hak tersebut. Dimana tidak semua orang mempunyai kemampuan lebih untuk mendapatkan tanah dan atau bangunan. Bea Perolehan Hak atas Tanah dan atau Bangunan (BPHTB) adalah pajak yang dikenakan atas perolehan hak atas tanah dan atau bangunan. Sebagaimana ketentuan peraturan perundang-undangan yaitu, UndangUndang Nomor 21 tahun 1997 jo. Undang-Undang Nomor 20 tahun 2000 tentang Perubahan atas Undang-Undang Nomor 21 tahun 1997 tentang Bea Perolehan Hak atas Tanah dan Bangunan. Yang kemudian pajak ini menjadi wewenang Pemerintah Kabupaten/kota sebagaimana amanat Undang-undang No. 28 Tahun 2009 tentang Pajak dan Retribusi Daerah Pasal 85 sampai dengan Pasal 93.

Transaksi jual beli atas tanah dan bangunan di Kabupaten Sidoarjo, penjual tanah dan bangunan dikenakan pajak Bea Perolehan Hak atas Tanah dan bangunan sedangkan pembeli tersebut dikenakan PPH dimana tata cara pemungutan bea perolehan hak atas tanah dan bangunan ini diatur di Peraturan Bupati no.21 tahun 2017 tentang tata cara pemungutan bea perolehan hak atas tanah dan bangunan . Dalam tata cara pemungutan BPHTB ini mencakup seluruh rangkaian proses dari menerima, menatausahakan, menagih dan melaporkan penerimaan dari BPTHB . Pada Pasal 2 Perbup No.21 tahun 2017 dijelaskan bahwa tata cara ini meliputi:

a. Pengurusan Pemindahan Hak atas Tanah dan Bangunan.Untuk pengurusan pemindahan hak atas tanah dan bangunan tersebut diterbitkan oleh PPAT/ Notaris atau dari pejabat lelang;

b. Pemeriksaan NPOP BPHTB. Pemeriksaan dari NPOPBPHTB tersebut dilakukan pemeriksaan yang dilaksanakan oleh badan atas suatu kebenaran dari nilai perolehan objek pajak yang sesuai dengan terutangnya pajak dan kelengkapan dokumen pendukung lainnya;

c. Pembayaran BPHTB. Merupakan pembayaran dari pajak yang terutang yang dilakukan oleh wajib pajak degan menggunakan SSPD;

d. Pemeriksaan pembayaran SSPD BPHTB. Pemeriksaan ini dilakukan oleh badan atas kebenaran perhitungan NPOP, perhitungan pajak dan kelengkapan SSPD dan dokumen pendukung;

e. Pelaporan BPHTB. Pada pelaporan ini mengenai realisasi penerimaan BPHTB dan akta pemindahan hak;

f. Penagihan BPHTB. Penagihan ini mengenai penetapan dari STPD, SKPDKB, SKPDLB, SKPDKBT, SKPDN, dan surat teguran oleh badan; 
g. Pengurangan BPHTB. Pengurangan ini dari penetapan persetujuan/ penolakan atas pengajuan pengurangan BPHTB yang diajukan oleh wajib pajak;

h. pengembalian atas kelebihan pembayaran BPHTB. Pengembalian ini dapat dilaksanakan apabila pembayaran pajak tersebut melebihi dari jumlah pajak terutangnya;

Untuk melaksanakan ketentuan yang dijelaskan diatas tersebut, pada Pasal 4 dijelaskan bahwa badan tersebut memiliki fungsi yang sebagai berikut:

a. Pelaksana fungsi pelayanan. Badan merupakan pelaksana fungsi pelayanan yang dimaksud disini berinteraksi dengan wajib pajak dalam setiap tahapantahapan pemungutan BPHTB.

b. Pelaksana fungsi data dan informasi, yang dimaksud ini mengenai mengelola data base terkait dengan objek pajak yang yang antara lain nilai transaksi, nilai pasar dan NJOP

c. Pelaksana fungsi Pemeriksaan. Melakukan pemeriksaan NPOP BPHTB dan pemeriksaan atas pembayaran BPHTB.

d. Pelaksana fungsi pembukuan dan pelaporan. Dalam hal ini menyiapkan laporan realisasi penerimaan BPHTB berdasarkan data dan laporan dari pihak-pihak lain yang ditunjuk.

\section{Implementasi Pemungutan BPHTB}

Berdasarkan pengenaan sebagaimana dimaksud maka memunculkan persoalan yaitu Petugas Penetapan Pajak tidak sepakat dengan laporan yang disampaikan oleh wajib pajak maka harga transaksi diangap tidak wajar, untuk mengukur ketidak wajaran maka petugas pajak secara subyektif padahal ketentuan penetapan pajak sudah berdasarkan harga transaksi, hal ini mengakibatkan ada beberapa permasalahan yaitu ketidakpastian penetapan obyek pajak sehingga perbedaan ini seharusnya tidak terjadi, sebagaimana penulis melakukan survey kepuasan pelayanan pemungutan BPHTB kepada Ikatan Notaris Indonesia (INI) maupun Ikatan Pembuat Akta Tanah (IPAT) di sekretariat masing-masing di Kabupaten Sidoarjo diperoleh infomasi bahwa sebagian besar subyek pajak BPHTB mempersoalan cara penetapan diluar ketentuan regulasi yang ada namun tidak dapat berbuat apa apa karena membutuhkan peralihan hak atas tanah atau bangunan yang dalam penguasaanya.

Ketidaksesuaian dasar penetapan regulasi ini seharusnya menjadi perhatian utama dalam review regulasi Perundang-undangan diantaranya Undang-undang 
Nomor 28 Tahun 2009 tentang Pajak dan Retribusi Daerah serta Peraturan Daerah Kabupaten Sidoarjo tentang Bea Perolehan Hak Atas Tanah dan Bangunan, agar harmonisasi pelayanan pajak khusunya pemungutan BPHTB dan kepastian hukum layanan BPHTB dimaksud. Bilamana dipandang perlu, sengketa perpajakan didelegasikan di daerah Kabupaten Kota sesuai dengan kompetensi absulut rumpun peradilan berdasarkan ketentuan perundang-undangan yang berlaku, agar supaya tindakan sewenang-wenang dalam penepatan BPHTB dapat dihindari dan kepastian hukum penetapan BPHTB dapat diwujudkan.

\section{Upaya Keberatan dan Banding dalam Peraturan Daerah Sidoarjo No.5 tahun} 2010

Pada Pasal 22 ayat (1) dijelaskan bahwa wajib pajak dapat mengajukan suatu keberatan hanya kepada Bupati atau pejabat yang ditunjuk atas suatu:

a. SKPDKB;

b. SKPDKBT;

c. SKPDLB;

d. SKPDN; dan

e. pemotongan atau pemungutan oleh pihak ketiga berdasarkan ketentuan peraturan perundang-undangan.

Pada Pasal 22 ayat (2),(3),(4) dijelaskan syarat yang harus dipenuhi oleh wajib pajak dalam mengajukan keberatan ini antara lain:

1. Keberatan diajukan secara tertulis dan dalam bahasa Indonesia dengan disertakan dengan alasan-alasan yang jelas.

2. Jangka waktu untuk mengajukan keberatan ini paling lama 3 (tiga) bul sejak tanggal surat, tanggal pemotongan atau pemungutan sebagaimana dijelaskan dalam ayat 1 Pasal 22 , kecuali jika wajib pajak tersebut dapat menunjukkan bukti bahwa jangka waktu yang itu tidak dapat dipenuhi karena keadaan di luar kekuasaannya.

3. Keberatan tersebut dapat diajukan ketika wajib pajak telah membayar paling sedikit sejumlah yang telah disetujui oleh wajib pajak.

Dari ketiga syarat tersebut jika tidak terpenuhi maka tidak akan dianggap sebagai surat keberatan sehingga hal tersebut tidak dapat dipertimbangkan namun 
apabila surat keberatan tersebut dapat dipenuhi maka terdapat tanda penerimaan surat keberatan yang diberikan oleh bupati atau pejabat yang ditunjuk atau tanda pengiriman surat keberatan dikirim melalui surat pos sebagai bukti bahwa surat keberatan tersebut diterima. Dalam hal ini bupati diberikan jangka waktu paling lama selama 12 (dua belas) bulan, sejak tanggal surat keberatan tersebut diterima dan harus memberikan suatu keputusan dapat berupa menerima seluruhnya atau sebagian, menolak, atau menambah besarnya pajak yang terutang terhadap keberatan yang diajukan oleh wajib pajak namun apabila jangka waktu yang diberikan telah lewat dan Bupati tidak memberikan suatu keputusan tersebut maka keberatan yang telah diajukan wajib pajak tersebut dianggap dikabulkan pengaturan ini terdapat dalam Pasal 23. Pada Pasal 25 ayat (3) dan (4) dijelaskan apabila keberatan ini ditolak atau dikabulkan sebagian maka wajib pajak dikenai sanksi administratif sebesar 50\% (lima puluh persen) dari jumlah pajak berdasarkan keputusan keberatan dikurangi dengan pajak yang telah dibayar sebelum mengajukan keberatan dan apabila wajib pajak mengajukan permohonan banding maka denda 50\% tersebut yang dimaksud di dalam ayat (3) tidak dikenakan.

Apabila wajib pajak merasa hasil dari keberatan yang telah diberikan maka dalam Pasal 24 dijeaskan mengenai syarat pengajuan dari upaya banding yang antara lain:

1. Wajib pajak dapat mengajukan permohonan banding hanya kepada Pengadilan Pajak terhadap keputusan mengenai keberatan yang telah ditetapkan oleh Bupati;

2. Permohonan banding sebagaimana dimaksud pada ayat (1) diajukan secara tertulis dalam bahasa Indonesia, dengan alasan yang jelas dalam jangka waktu 3 (tiga) bulan sejak keputusan diterima, dilampiri dengan salinan dari surat keputusan keberatan tersebut;

3. Pengajuan permohonan banding menangguhkan kewajiban pembayaran pajak sampai dengan 1 (satu) bulan sejak tanggal penerbitan putusan banding.

Dari penjelasan kedua upaya hukum diatas apabila pengajuan dari upaya keberatan dan hukum tersebut dikabulkan sebagian atau seluruhnya maka kelebihan 
pembayaran pajak dikembalikan dan juga ditambahkan dengan imbalan 2\% (dua persen) sebulan untuk paling lama 24 (dua puluh empat) bulan. Imbalan bunga yang diberikan tersebut dihitung sejak bulan pelunasan sampai diterbitkannya SKPDLB.

\section{Pemeriksaan Kepatuhan Wajib Pajak dalam Pembayaran Pajak Daerah Pada Peraturan Daerah Sidoarjo No.5 tahun 2010}

Pada kenyataan yang terjadi di lapangan jika terjadi suatu permasalahan pajak yang mana dalam permasalahannya tersebut dapat menjadi suatu sengketa pajak hal ini jarang terjadi, karena sengketa pajak merupakan jalan terakhir yang digunakan oleh wajib pajak untuk mengajukan keberatan terhadap surat keputusan yang dikeluarkan oleh petugas pajak namun juga terdapat beberapa kasus dimana terdapat seorang wajib pajak yang memiliki utang pajak dimana wajib pajak tidak mau untuk membayar utang pajaknya yang dikarenakan karena banyak hal bisa karena adanya perbedaan penghitungan dengan petugas pajak sehingga hal ini dapat menjadi suatu sengketa pajak namun sengketa tersebut selalu dapat dihindarkan karena ketika terdapat suatu peringatan-peringatan dari fiskus wajib pajak sudah melakukan pembayarannya namun terdapat juga wajib pajak tersebut yang tidak mampu untuk membayar sehingga dalam hal ini fiskus akan melakukan yang namanya pemeriksaan dikarenakan di beberapa kasus ini harus diperiksa apakah dalam pelunasan utang pajak oleh wajib pajak sudah sesuai aturan maupun belum dikarenakannya juga wajib pajak menggunakan sistem self assesment yang mana hal ini sangat memungkinkan para wajib pajak tersebut tidak jujur dalam melaporkan dan membayar pajak daerah yang sesuai dengan peraturan perundang-undangan yang berlaku sehingga hal ini juga dapat menyebabkan kurang maksimalnya pendapatan suatu daerah selain permasalahan diatas tersebut kasus yang paling sering terjadi karena penetapan nilai jual objek pajak yang masih rendah dan juga nilai pasar yang masih juga rendah hal ini sering terjadinya keberatan oleh wajib pajak yang mana dikarenakan di daerah sidoarjo menetapkan suatu sistem zonasi yang mana harga dari setiap tanah diwilayah akan berbeda sehingga hal ini sering menimbulkan perselisihan antara wajib pajak dengan penetapan nilai pajak yang ditetapkan oleh 
pemerintah kabupaten daerah sidoarjo/Badan Pelayanan Pajak Daerah Kabupaten Sidoarjo sehingga untuk menentukan suatu permasalahan tersebut digunakan yang namanya suatu pemeriksaan. Pemeriksaan ini sendiri salah satu tujuannya adalah sebagai pengujian kepatuhan terhadap wajib pajak dalam memenuhi kewajiban pajaknya. Pengertian pemeriksaan pajak adalah serangkaian kegiatan untuk mencari, mengumpulkan, mengelola data dan atau keterangan lainnya untuk menguji kepatuhan pemenuhan kewajiban perpajakan dan untuk tujuan lain dalam ranka melaksanaka ketentuan peraturan perundang-undangan perpajakan. ${ }^{3}$ Pemeriksaan pajak ini sendiri wajib ini diatur di dalam Peraturan Daerah Sidoarjo no.5 tahun 2010 Pasal 30 ayat (1) yang bunyinya Bupati berwenang melakukan pemeriksaan untuk menguji kepatuhan pemenuhan kewajiban perpajakan daerah dalam rangka melaksanakan peraturan perundang-undangan perpajakan daerah. Ayat (2) menjelaskan bahwa wajib pajak yang diperiksa wajib:

a. Memperlihatkan dan/atau meminjamkan buku atau catatan, dokumen yang menjadi dasarnya dan dokumen lain yang berhubungan dengan objek pajak yang terutang;

b. Memberikan kesempatan untuk memasuki tempat atau ruangan yang dianggap perlu dan memberikan bantuan guna kelancaran pemeriksaan;

c. Memberikan keterangan yang diperlukan.

Pada ayat (3) ketentuan lebih lanjut mengenai tata cara pemeriksaan pajak diatur dengan Peraturan Bupati no.21 tahun 2017, namun selanjutnya yang perlu diperhatikan adalah fungsi pengawasan/control karena Penyidik Pegawai Negeri Sipil adalah fungsional jabatan, yang bertindak untuk dan atas nama jabatan atau melaksanakan tugas, fungsi, dan kewenangan yang melekat pada pejabat. Tindakan dalam jabatan tersebut itu didasarkan pada asas legalistas mengandung arti mendasarkan tindakan itu pada kewenangan terikat (gebondend bevoegdheid). Tindakan itu terkait adanya kewenangan adalah pertanggungjawaban sesuai dengan prinsip "geen bevoegdheid zonder verantwoordelijkheid" (tidak ada kewenangan

3 Mardiasmo, Perpajakan (Andi Publisher 2013).[35]. 
tanpa pertanggungjawaban). Lebih lanjut menurut pendapat Tatiek Sri Djatmiati mengemukakan:

"Setiap penggunaan kewenangan apapun bentuknya apakah dalam rangka pengaturan, pengawasan, maupun penentuan sanksi oleh badan pemeritah selalu disertai dengan adanya tanggungjawab. Hal ini merupakan suatu keharusan, oleh karena didalam konsep hukum administrasi pemberian kewenangan dilengkapi dengan pengujiannya dan bahwa kesalahan dalam penggunaan kewenangan, selalu berakses kepengadilan, sehingga menjamin perlindungan hukum. Di dalam kerangka kerja yang demikian, maka misi untuk perlindungan hukum haruslah diarahkan guna melindungi kepentingan individu dan untuk kontrol atas kewenangan dari pemerintah. Dalam kaitan ini bagi individu yang telah dirugikan selalu terdapat upaya kepangadilan untuk melindungi hak-haknya dalam melawan perbuatan pemerintah yang dianggap keliru atau merugikan masyarakat".

PPNS adalah jabatan pemerintahan, yakni lingkungan pekerjaan tetap yang melekat dengan wewenang untuk menyelenggarakan urusan pemerintahan, yakni semua tugas-tugas kenegaran selain bidang pembuatan undang-undang dan peradilan, " elke werkzaamheid van de overheid, welke niet als wetgeving of als rechtspraak is aan te merken. Organ pemerintah melakukan tindakan hukum, juga melakukan tindakan nyata (feitelijke handeling) seperti pemeriksaan pajak, pemasangan papan nama jalan dan sebagainya. Tidak semua tindakan pemerintah yang menimbulkan kerugian bagi seseorang atau badan hukum swasta itu melahirkan hak gugat dan ganti kerugian, kecuali dalam tindakan pemerintah itu ada unsur onrechmatige overheidsdaat. Jika unsur onrechmatige overheidsdaat itu tidak ada, hak gugat dan ganti kerugian itu tidak ada meskipun tindakan pemerintah itu menimbulkan kerugian bagi warga Negara. ${ }^{4}$

Berkaitan dengan penetapan nilai BPHTB mendasari harga transaksi sudah harusnya menjunjung tinggi kesepakatan dalam nilai transaksi namun pada kenyataan nya Pejabat pengawas yang disebut PPNS Pajak tidak mengunakan ketentuan transaksi namun mengunakan pemeriksaan pajak dengan subyektif menggunakan metoda harga pasaran umum dan zonasi yang tidak ada dasar

${ }^{4}$ Sufriadi, 'Tanggung Jawab Jabatan Dan Tanggung Jawab Pribadi Dalam Penyelenggaraan Pemerintahan Di Indonesia'(2014) 1 Jurnal Yuridis.[60]. 
yuridisnya yang menimbulkan permasalahan baru yaitu ketidakpastian dalam penetapan BPHTB. Dengan demikian pengertian dalil transaksi dalam penetapan BPHTB bertentangan dengan skema penetapan yang dilakukan dalam Pelayanan Pajak Daerah. Karena pada prinsipnya pelaksanaan transaksi lebih mendekatkan pada keperdataan yang mengarah pada kesepakatan yang tertuang dalam perjanjian dan terikat pada beberapa asas, antara lain:

1. Asas kebebasan berkontrak Para pihak bebas untuk menentukan isi, bentuk, ataupun jenis kontrak sesuai kesepakatan diantara mereka dan perjanjian itu mengikat mereka yang membuatnya seperti suatu undang-undang.

2. Asas konsensualisme

Pada dasarnya perikatan yang ada pada suatu perjanjian timbul sejak tercapainya suatu kesepakatan mengenai hal-hal yang pokok dari perjanjian itu.

3. Asas mengikat (Pacta Sunt Servanda)

Semua perjanjian sah yang dibuat oleh para pihak mengikat kedua pihak seperti halnya undang-undang. Kewajiban-kewajiban yang timbul karena perikatan tersebut, merupakan kewajiban hukum yang dapat dipaksakan. Dan perjanjian tersebut harus dilaksanakan oleh para pihak dengan iktikad baik.

4. Asas kepercayaan (Vertrouwensbegisel)

Dengan kepercayaan, maka para pihak dapat mengikatkan diri dengan suatu perjanjian. Kepercayaan bahwa para pihak satu sama lain akan memegang janji bahwa para pihak akan memenuhi prestasinya di belakang hari.

5. Asas Persamaan Hukum

Asas ini menempatkan pihak dalam kedudukan yang sederajat, tidak ada perbedaan kulit, bangsa, kekayaan, kekuasaan, dan jabatan. Masing-masing pihak harus melihat persamaan ini dan saling menghormati satu sama lainnya.

6. Asas Keseimbangan

Asas ini menghendaki kedua pihak memenuhi dan melaksanakan isi perjanjian. Dengan perjanjian ini para pihak harus melaksanakan perjanjian dengan iktikad baik dan dapat menuntut prestasi kepada pihak lain. Dengan demikian, posisi para pihak adalah seimbang.

7. Asas Kepastian Hukum

Asas ini terkandung didalam kekuatan mengikatnya suatu perjanjian seperti halnya undang-undang.

8. Asas Moral

Perbuatan hukum untuk melakukan kewajiban hukum yang tertuang didalam suatu perjanjian harus didasarkan pada iktikad baik. Dan iktikad baik ini merupakan suatu moral tiap diri manusia.

9. Asas Kepatutan

Asas ini terkandung dalam Pasal 1339 BW yang berkaitan dengan isi suatu perjanjian. Asas ini ukurannya adalah rasa keadilan yang ada pada masyarakat

10. Asas kerja sama yang saling menguntungkan 
Antara para pihak dalam peralihan ha katas tanah atau bangunan terdapat prinsip saling menguntungkan

11. Asas Kepastian Hukum

Asas kepastian hukum berarti bahwa dengan perjanjian/ perikatan maka terjadi kepastian hukum pula peralihan antara pihak. ${ }^{5}$

Dengan demikian transaksi dalam penetapan BPHTB lebih mengarah kepada kesepakatan dalam perjanjian jual beli antara PARA PIHAK sebagai acuan dalam menetapkan BPHTB.

\section{Kesimpulan}

Pemungutan pajak ini sudah diatur didalam undang-undang yang berlaku namun tetap saja terdapat permasalahan yang timbul dikarenakan sesuai perundangundangan adalah transaksi namun oleh petugas pemungutan BPHTB ditentukan mengunakan harga pasar, zonasi atau lainnya sesuai dengan subyektifitas petugas pemungut, sehingga memunculkan ketidak pastian hukum serta Pada suatu pemeriksaan administrasi pajak BPHTB yang hanya merupakan melakukan pengecekan suatu pelaporan yang telah disetorkan oleh wajib pajak maka pihak yang berwenang untuk melakukan pemeriksaan tersebut merupakan dari PNS yang mana telah ditunjuk namun jika dalam suatu sengketa pajak atau terdapat tindak pidana perpajakan maka di sini kewenangan pemeriksaan tersebut diberikan kepada PPNS sebagai aparat penyidik tindak pidana dalam lingkup bidang tugasnya perpajakan melaksanakan penyidikan di bawah koordinasi oleh penyidik Polri merupakan bagian dari sistem peradilan pidana karena dalam melaksanakan tugas dan fungsinya bekerjasama dan berinteraksi dengan subsistem-subsistem penegak hukum lain dalam kerangka system peradilan pidana , namun dalam pelayanan BPHTB lebih berperan dalam ranah pemeriksaan dalam rangka penetapan BPHTB belum mengarah pada Pidana Perpajakan khsusunya BPHTB sehingga seharusnya perbaikan sistem mengenai norma dan prosedur pemeriksaan dalam rangka penetapan BPHTB.

\footnotetext{
5 Mariam Darus Badrulzaman, Kompilasi Hukum Perikatan (Citra Aditya 2001).[39].
} 


\section{Daftar Bacaan}

\section{Buku}

Mardiasmo, Perpajakan (Andi Publisher 2013).

Mariam Darus Badrulzaman, Kompilasi Hukum Perikatan (Citra Aditya 2001).

Peter Mahmud Marzuki, Penelitian hukum edisi revisi (Kencana Pramedia Grup 2015).

\section{Jurnal}

Najah Aqila Yunisha Kiai Demak dan Linda Lambey, 'Evaluasi Pemungutan Bea Perolehan Hak Atas Tanah dan Bangunan (BPHTB) di Dinas Pendapatan Pengelolaan Keuangan dan Aset Daerah (DPPKAD) Kota Gorontalo'(2016) 4 Jurnal Emba.

Sufriadi, 'Tanggung Jawab Jabatan Dan Tanggung Jawab Pribadi Dalam Penyelenggaraan Pemerintahan Di Indonesia', (2014) 1 Jurnal Yuridis.

\section{Perundang-Undangan}

Undang-Undang Dasar Negara Republik Indonesia 1945.

Undang Nomor 21 tahun 1997 tentang Bea Perolehan Hak Atas Tanah dan Bangunan. (Lembaran Negara Republik Indonesia Tahun 1997 Nomor 44, Tambahan Lembaran Negara Republik Indonesia Nomor 3688).

Undang-Undang Nomor 28 tahun 2009 tentang Pajak Daerah dan Retribusi Daerah. (Lembaran Negara Republik Indonesia Tahun 2009 Nomor 130, Tambahan Lembaran Negara Republik Indonesia Nomor 5049).

Peraturan Daerah Kabupaten Sidoarjo Nomor 5 tahun 2010 tentang Bea Perolehan Hak Atas Tanah dan Bangunan. (Lembaran Daerah Kabupaten Sidoarjo Tahun 2010 Nomor 1 Seri B, Tambahan Lembaran Daerah Kabupaten Sidoarjo Nomor 14).

Peraturan Bupati Sidoarjo Nomor 21 Tahun 2017 Tentang Tata Cara Pemungutan Bea Perolehan Hak Atas Tanah Dan Bangunan. ( Berita Daerah Kabupaten Sidoarjo Tahun 2017 Nomor 21). 
Dhimas Adhi: Penyelesaian Sengketa Pajak

--halaman ini sengaja dibiarkan kosong-- 